\title{
Clinical Role for a Superantigen in Yersinia pseudotuberculosis Infection
}

\author{
Jun Abe, ${ }^{*}$ Michiko Onimaru, ${ }^{\star}$ Shinichi Matsumoto," Seiji Noma," Kiyoshi Baba, ${ }^{\star \star}$ Yasuhiko Ito,‡ Takao Kohsaka, ${ }^{\ddagger}$ \\ and Tae Takeda $\$$ \\ *Department of Child Ecology, ${ }^{\ddagger}$ Department of Immunology, and ${ }^{\S}$ Department of Infectious Diseases Research, The National Children's \\ Hospital Medical Research Center, Tokyo 154, Japan; "Department of Pediatrics, Yamaga Municipal Hospital, Kumamoto 861, Japan; \\ "Department of Pediatrics, Hachioji Metropolitan Children's Hospital, Tokyo 193, Japan; and **Division of Pediatrics, Heart Institute, \\ Kurashiki Central Hospital, Okayama 710, Japan
}

\begin{abstract}
Yersinia pseudotuberculosis is an enteric pathogen that causes a variety of clinical symptoms in the human. Recently, we reported the production of a superantigen ( $Y$. pseudotuberculosis-derived mitogen, YPM) by this organism and characterized the gene structure of ypm. To further study the potential pathogenic role of YPM in Y. pseudotuberculosis infection, we assayed IgG anti-YPM antibodies and $T$ cell antigen receptor- $\mathrm{V} \beta$ expression of the $T$ cells in peripheral blood and in mesenteric lymph node in patients acutely infected with Y. pseudotuberculosis. 20 out of 33 patients $(61 \%)$ had an elevated antibody titer compared with healthy controls $(P=0.0001)$. Patients with systemic symptoms such as lymphadenopathy, transient renal dysfunction, and arthritis had significantly higher titers of antiYPM than patients with gastrointestinal tract symptoms alone. $T$ cells bearing the $V \beta 3$ gene segment were significantly increased $(P=0.009)$ among acute phase patients compared with healthy children. During the convalescence phase of the illness, there was a reduction in the abnormal level of V $\beta 3 \mathrm{~T}$ cells. Moreover, in the mesenteric lymph node, an elevated level of $\mathrm{V} \beta 3 \mathrm{~T}$ cells compared with peripheral blood and a sequence diversity in the junctional region of the $T$ cell antigen receptor $\beta$-chain containing $V \beta 3$ element was observed in one patient. Together, these findings suggest that YPM was produced in vivo and played an important role in the pathogenesis of $Y$. pseudotuberculosis infection. (J. Clin. Invest. 1997. 99:1823-1830.) Key words: polymerase chain reaction $\cdot \mathrm{T}$ cells • Kawasaki syndrome • arthritis • enzyme-linked immunosorbent assay
\end{abstract}

\section{Introduction}

Yersinia pseudotuberculosis is a Gram-negative coccobacillus and a primary pathogen of wild and domestic animals and birds. In the human, Y. pseudotuberculosis causes varying degrees of illnesses from diarrhea and abdominal pain to more systemic symptoms such as fever, scarlatiniform skin rash, con-

Address correspondence to Jun Abe, Department of Child Ecology, National Children's Hospital Medical Research Center, 3-35-31, Taishido, Setagaya-ku, Tokyo 154, Japan. Phone: 03-3414-8121; FAX: 03-3414-8321; E-mail: jabe@nch.go.jp

Received for publication 11 October 1996 and accepted in revised form 4 February 1997.

J. Clin. Invest.

(C) The American Society for Clinical Investigation, Inc.

0021-9738/97/04/1823/08 \$2.00

Volume 99, Number 8, April 1997, 1823-1830 junctivitis, erythema nodosum, and lymphadenopathy (1-3). Complications of reactive arthritis, acute uveitis, coronary aneurysms, and acute renal failure are not infrequently reported (4-8). The mechanisms by which the organism mediates these symptoms are poorly understood. However, the preferential avidity for lymphoid tissues seen in this bacterium and the characteristic histopathological finding of lymphoid hyperplasia mainly seen in mesenteric lymph nodes $(9,10)$ suggest that the stimulation of a large proportion of $\mathrm{T}$ cells may be involved in the pathogenesis of this infection.

$Y$. pseudotuberculosis has been described to produce a superantigen, Y. pseudotuberculosis-derived mitogen (YPM) ${ }^{1}$ $(11,12)$. Superantigens are a class of viral or bacterial proteins that mediate activation of the immune system by direct interaction with both MHC class II molecules and the variable region of the $T$ cell antigen receptor (TCR) $\beta$ chain (13-17). After contact with superantigens in vivo, a large proportion of $\mathrm{T}$ cells are expanded, deleted, or anergized in a TCR V $\beta$-dependent manner $(14,18,19)$. In the previous studies, we have demonstrated that YPM selectively stimulates $\mathrm{T}$ cells bearing $\mathrm{V} \beta 3,9,13.1$, and 13.2 gene segments $(11,20)$ and that the distribution of the ypm gene among the isolates from diverse geographical areas was in close correlation with the difference in the severity of clinical manifestations between the different areas (21). Interestingly, the frequency of YPM-producing strains was higher in the Far East than in Europe, where systemic symptoms in the infected patients are less common compared with the Far East and the United States (21-25). Based on these findings, the current study was carried out to determine whether a superantigen, YPM, is actually produced in patients acutely infected with $Y$. pseudotuberculosis and has influences on the patients' immune systems. For this purpose, we assayed IgG anti-YPM antibodies and analyzed TCR-V $\beta$ expression of the $T$ cells in peripheral blood and in mesenteric lymph node from the patients.

\section{Methods}

Patients. 33 patients ( 21 males and 12 females, ages ranged from $1 \mathrm{yr}$, 11 mo to $25 \mathrm{yr}$, median $5 \mathrm{yr}, 3 \mathrm{mo}$ ) with $Y$. pseudotuberculosis infection were studied. The diagnosis was made when a patient with fever and/or gastrointestinal tract symptoms had a positive rectal swab culture of the organism and/or had an elevated agglutination titer against the heat-killed organism (standard strains of each O serotype of Y. pseudotuberculosis were a gift from Dr. S. Kaneko, Tokyo Metropolitan Research Laboratory of Public Health). Five patients under-

1. Abbreviations used in this paper: $\mathrm{C} \alpha, \alpha$ chain constant region; IVGG, intravenous gamma globulin; MBP, maltose-binding protein; TCR, $T$ cell antigen receptor; $\mathrm{V} \beta, \beta$ chain variable region; TSS, toxic shock syndrome; YPM, Yersinia pseudotuberculosis-derived mitogen. 
went surgery because of severe gastroenteritis mimicking acute abdomen. Five patients had transient renal dysfunction, two of whom required hemodialysis. Cervical lymphadenopathy and conjunctivitis were seen in 16 and 17 patients, respectively. Aneurysms or dilatation of the coronary arteries $(>5 \mathrm{~mm}$ ) and/or pericardial effusion were seen in eight patients. Sera were obtained for analysis of anti-YPM antibodies from 33 patients during the acute phase of the illness (within $33 \mathrm{~d}$ from the onset of fever). For analysis of $\mathrm{T}$ cells, venous blood was available from 14 patients in acute phase, from whom we were able to obtain seven paired samples from the acute and convalescence phase ( $>120 \mathrm{~d}$ from the onset of fever). 65 sera and 14 venous blood samples from the healthy children were studied as controls. Mesenteric lymph nodes were obtained from a yersiniosis patient and a control patient who underwent surgery because of acute appendicitis. Informed consent was obtained from either the patient or the child's parents according to the guidelines of each medical center to which the patients were referred.

Preparation of recombinant YPM. Recombinant YPM (rYPM) was purified from the cell lysate of transformed Escherichia coli as has been reported (20). Briefly, the transformant was cultured in 500 $\mathrm{ml}$ of Luria-Bertani medium and protein expression induced by IPTG (isopropyl- $\beta$-D-thiogalactopyranoside). After the bacteria were harvested and resuspended in $15 \mathrm{ml}$ of $20 \mathrm{mM}$ Tris- $\mathrm{HCl}, 200 \mathrm{mM} \mathrm{NaCl}, 1$ mM EDTA, pH 7.4, the cells were frozen-thawed and sonicated. The plasmid-encoded maltose-binding protein (MBP) and YPM fusion protein was affinity purified with an amylose resin and was next cleaved with a proteinase, Factor Xa (New England Biolabs Inc., Beverly, MA) (26). The rYPM was separated from a residual MBP by gel filtration on Superdex 200 (Pharmacia Biotech, Tokyo, Japan) in PBS (0.01 $\left.\mathrm{M} \mathrm{Na}_{2} \mathrm{HPO}_{4}, 0.8 \% \mathrm{NaCl}, \mathrm{pH} 7.4\right)$ with $50 \mathrm{mM} \mathrm{NaSCN}$, followed by extensive dialysis against PBS diluted to 1:50. The final preparation of the rYPM was examined by a $15 \%$ SDS-PAGE to give a sharp single band for its purity.

Assay of IgG anti-YPM antibodies. The ELISA was performed as described by Leung et al. (27) with modifications. Flat-bottomed microtiter plates (Nunc Inc., Roskilde, Denmark) were coated with $100 \mu \mathrm{l}$ of a $5-\mu \mathrm{g} / \mathrm{ml}$ solution of rYPM in $0.05 \mathrm{M} \mathrm{Na}_{2} \mathrm{CO}_{3}$ buffer, $\mathrm{pH}$ 9.5. The plates were covered and shaken overnight at $4^{\circ} \mathrm{C}$. After removing the solution, the plates were stored at $-20^{\circ} \mathrm{C}$. Before use, the plates were thawed to room temperature and washed five times with PBS supplemented with $0.05 \%$ Tween 20 (PBS-Tween). Nonspecific protein binding sites were blocked with $200 \mu \mathrm{l}$ of PBS containing $5 \%$ (wt/vol) skim milk for $2 \mathrm{~h}$ at room temperature. Both reference and test sera were diluted to 1:200 and 1:400 in PBS-Tween, and then 100 $\mu l$ of each dilution was applied into either an antigen-precoated or no antigen-coated well in duplicate. After incubation at room temperature for $2 \mathrm{~h}$, the plates were washed five times with PBS-Tween. Then, $100 \mu \mathrm{l}$ of 1:1,000 dilution of peroxidase-conjugated $\mathrm{F}\left(\mathrm{ab}^{\prime}\right)_{2}$ fraction of rabbit anti-human IgG specific for Fc (American Qualex Antibodies \& Immunochemicals Co., La Mirada, CA) was placed in the well. The plates were incubated at room temperature for $1 \mathrm{~h}$, and then washed five times with PBS-Tween. $100 \mu \mathrm{l}$ of $1 \mu \mathrm{g} / \mathrm{ml}$ solution of $o$-phenylenediamine dihydrochloride (Sigma Chemical Co., St. Louis, $\mathrm{MO}$ ) in $0.05 \mathrm{M}$ phosphate-citrate buffer, $\mathrm{pH}$ 5.0, was added in each well and the plates were incubated at room temperature for $10 \mathrm{~min}$, and then optical density was read at $492 \mathrm{~nm}$. In all experiments, OD of the no antigen-coated wells was $<0.01$ and was subtracted from the OD of the antigen-coated wells as background. Specificity of the assay was confirmed by the absorption of the reactive IgG by preincubation of the serum with soluble rYPM at $4^{\circ} \mathrm{C}$ overnight before the assay.

Western blot analysis. rYPM or rMBP control protein $(1 \mu \mathrm{g}$ per lane) was separated on a $20 \%$ SDS-polyacrylamide gel and transferred to PVDF membrane (Millipore Corp., Bedford, MA). The paired sera obtained from two patients between 6 and $21 \mathrm{~d}$ from the onset of the fever were diluted to 1:100 with TBS (20 mM Tris, $\mathrm{pH}$ $7.5,150 \mathrm{mM} \mathrm{NaCl}$ ) containing $2 \%$ (wt/vol) skim milk, and applied to the membrane. Bound IgG was detected with $100 \mu$ l of 1:1,000 dilu- tion of peroxidase-conjugated $\mathrm{F}\left(\mathrm{ab}^{\prime}\right)_{2}$ fraction of rabbit anti-human IgG (American Qualex Antibodies \& Immunochemicals Co.) and analyzed with a Quantity One ${ }^{\circledR}$ image analyzing system (PDI, Huntington Station, NY).

Lymphocyte cultures and assessment of TCR V $\beta$ expression. PBMC were isolated from heparinized blood by Ficoll-Hypaque density gradient centrifugation. The cells were stimulated for $3 \mathrm{~d}\left(37^{\circ} \mathrm{C}\right.$, $95 \%$ humidity, and $\left.5 \% \mathrm{CO}_{2}\right)$ with anti-CD3 $(20 \mathrm{ng} / \mathrm{ml}$, a gift from $\mathrm{Dr}$. $\mathrm{H}$. Yagita, Juntendo University, Tokyo), washed, and expanded for $1 \mathrm{~d}$ in IL-2 as previously described (14). Mesenteric lymph nodes were dissected, washed in PBS, and frozen at $-80^{\circ} \mathrm{C}$ until extraction of RNA. Two methods were then used to assess TCR V $\beta$ expression. The first method used a previously described semiquantitative reverse transcription-PCR (RT-PCR) method to estimate the proportion of $T$ cells expressing particular $\mathrm{V} \beta$ gene segments (28). In these experiments, $2 \mu \mathrm{g}$ of total RNA was used for the synthesis of first strand cDNA, and TCR $\beta$ and $\alpha$ chain cDNAs were coamplified using a V $\beta$-specific oligomer (corresponding to one of the $26 \mathrm{~V} \beta$ families analyzed) and an oligomer from the downstream $\beta$ chain constant region ( $\mathrm{C} \beta$ primer) as one pair, and two $\alpha$ chain constant region $(\mathrm{C} \alpha)$ primers as the other pair. The sequences of the specific primers used and details of the PCR have been published $(28,29)$. Amplification was performed with 23 cycles. For quantitation of amplified products, ${ }^{32} \mathrm{P}$ end-labeled $3^{\prime}$ primers $\left(\sim 10^{6} \mathrm{cpm}\right.$ each $)$ were added to the reactions. The amplified products were separated on $2 \%$ agarose gels, dried, and analyzed with a BAS2000 Bio Image Analyzer (Fujix Film Co., Tokyo, Japan). The percentage of each $\mathrm{V} \beta$ among all $\mathrm{V} \beta$ families studied was calculated after normalization with the amount of coamplified $\mathrm{C} \alpha$ band; i.e., percent $\mathrm{V} \beta=(\mathrm{V} \beta \mathrm{x} / \mathrm{C} \alpha \mathrm{x}) / \Sigma(\mathrm{V} \beta \mathrm{n} / \mathrm{C} \alpha \mathrm{n}) \times$ 100 (20).

The second method used immunofluorescence with biotinylated monoclonal antibodies directed at four different $\mathrm{V} \beta$ segments (14). The cells were incubated with either of the biotinylated monoclonal antibodies, E22E7.2, an antibody to V $\beta 2$; LE-89, an antibody to V 33 ; 56C5, an antibody to V $\beta 8.1$ and 8.2 (Immunotech, Marseille, France); or AMKB1-2, an antibody to V $\beta 9$ (Pharmingen, San Diego, CA), followed by incubation with phycoerythrin-conjugated streptavidin (1:50 dilution; PharMingen, San Diego, CA) and FITC-anti-Leu 4 (anti-CD3) (Becton Dickinson \& Co., San Jose, CA). Fluorescence intensity was analyzed with a FACScan ${ }^{\circledR}$ (Becton Dickinson \& Co.). The percentage of $\mathrm{T}$ cell blasts bearing each receptor phenotype was expressed as a percentage of $\mathrm{CD} 3$ positive cells.

Cloning and sequencing of TCR $\beta$ chain junctional regions. $2 \mu \mathrm{g}$ of total RNA prepared from dissected mesenteric lymph node was used for the synthesis of first-strand cDNA followed by PCR with V $\beta 3$ and $C \beta$ primers. After 30 cycles of $\mathrm{PCR}$, the products were ligated into pT7Blue T-Vector (Novagen Inc., Madison, WI) and transfected into competent $E$. coli. 20 independent transformants were randomly selected and each cloned plasmid DNA was restored by the alkali-lysis method and sequenced by Sequenase Ver2.0 kit (Amersham Life Science, Cleveland, $\mathrm{OH}$ ) using $\mathrm{C} \beta$ primers.

\section{Results}

Detection of IgG anti-YPM in patients with Y. pseudotuberculosis infection. The sera from the 33 patients with $Y$. pseudotuberculosis infection were tested for the presence of IgG antiYPM antibodies by ELISA. In 22 patients, sera were obtained serially during the course of the illness. Fig. 1 illustrates the highest OD value obtained from each patient between 9 and $33 \mathrm{~d}$ from the onset of the disease. Among the patients, the mean OD value was significantly higher than in controls $(0.401 \pm 0.045$ vs. $0.139 \pm 0.009$ (mean \pm SEM),$P=0.0001)$. In 20 of $33(61 \%)$ patients, OD values exceed 2 SD above the value obtained for healthy children. When the sequentially obtained sera were examined, high OD values were seen after 


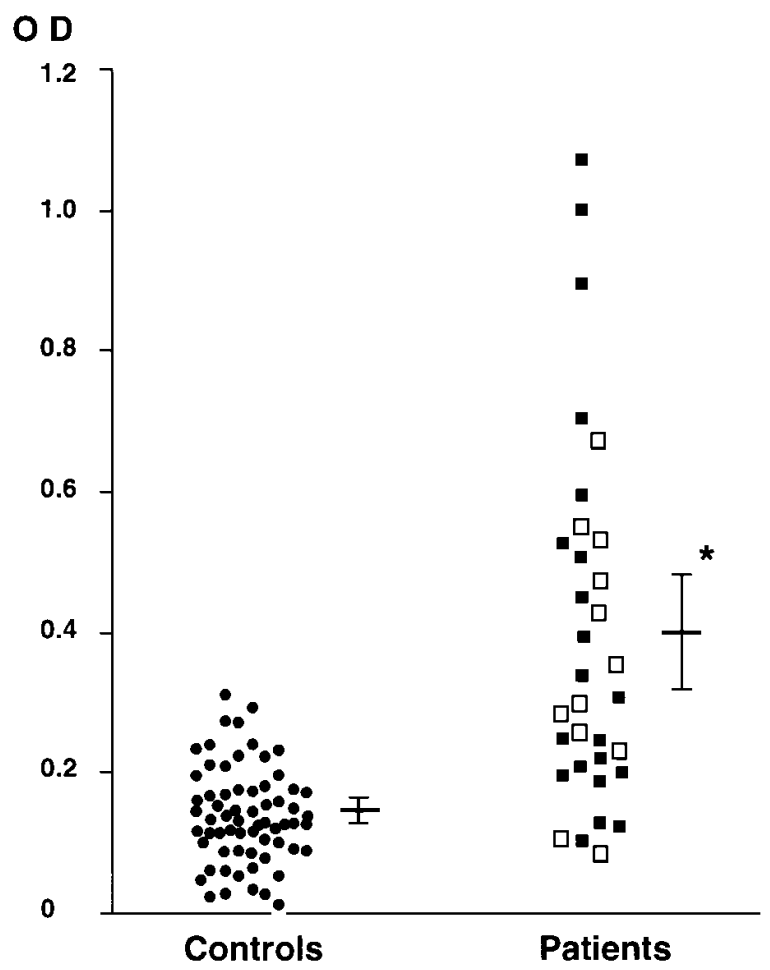

Figure 1. IgG anti-YPM antibodies in patients with $Y$. pseudotuberculosis infection measured by ELISA. The sera obtained from IVGG-treated ( $\square$ ) or untreated ( $\square$ ) patients and healthy children (@) were diluted to 1:400 and applied to either an antigen-coated $(5 \mu \mathrm{g} / \mathrm{ml})$ or no antigen-coated well. In all experiments, OD of the no antigen-coated wells was $<0.01$ and was subtracted from the OD of the antigen-coated wells. Each bar indicates the mean \pm 2 SEM. $* P=0.0001$ by Student's $t$ test.

the second week of the illness (data not shown). Because some patients were treated with the high dose of intravenous gamma globulin (IVGG) as indicated in Fig. 1, we were concerned with the possibility that the immunoglobulin used for the therapy contained anti-YPM antibodies. When two different preparations of IVGG in the concentration of 10 and $20 \mathrm{mg} / \mathrm{ml}$ were tested by ELISA, they gave OD values of 0.139 and 0.238 , respectively. No difference in OD values was observed between different preparations. Neither was there any significant difference in OD value between the patients who received IVGG and those who did not.

$Y$. pseudotuberculosis infections are accompanied by multiple systemic symptoms other than the gastrointestinal tract symptoms. Therefore, we compared the anti-YPM titer as well as WBC count, c-reactive protein (CRP), glutamic oxaloacetic transaminase, glutamic pyruvic transaminase, and agglutination titer for the heat-killed bacteria, between the patients with and without systemic symptoms. Although CRP values among the patients with systemic symptoms were higher than in patients with more localized symptoms $(13.8 \pm 2.4 \mathrm{vs} .7 .8 \pm 2.4 \mathrm{mg} /$ $\mathrm{ml}, P=0.16$ ), other laboratory data failed to show positive correlation with systemic manifestations of the illness. On the other hand, anti-YPM titer among the patients who had systemic illnesses was significantly increased compared with the patients who did not $(0.458 \pm 0.05$ vs. $0.220 \pm 0.04, P=0.02$, Fig. $2)$. In both groups, the anti-YPM titer was measured in com-

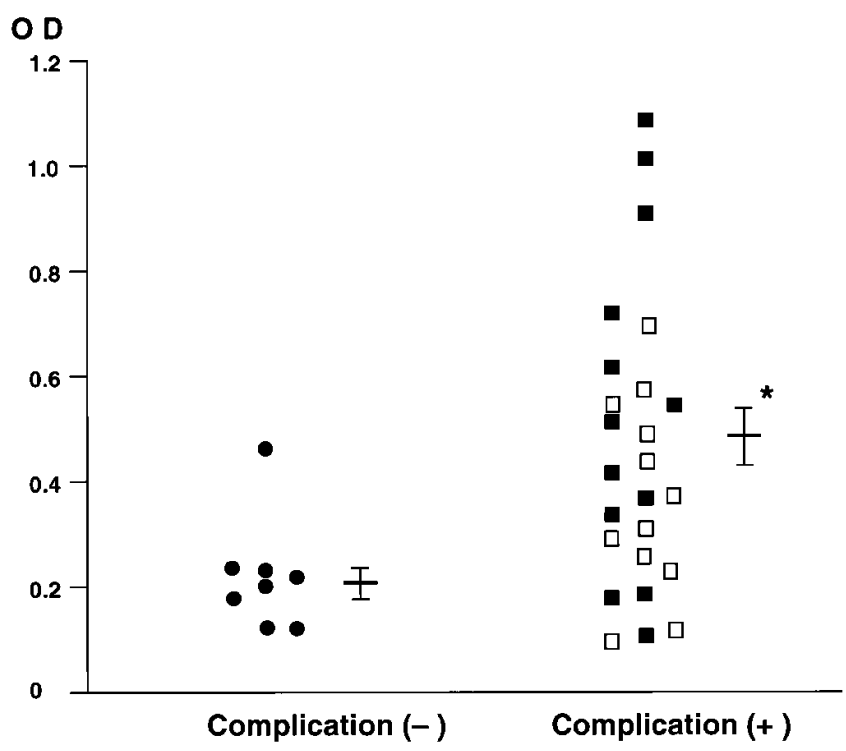

Figure 2. Higher anti-YPM titers among the patients with systemic complications. The patients with Y. pseudotuberculosis infection were classified by the presence ( $\square$ for IVGG untreated and $\square$ for IVGG treated) or the absence ( $)$ of the systemic complications (renal dysfunction, acute abdomen, arthritis, lymphadenopathy, and coronary aneurysms). Anti-YPM antibodies determined by ELISA were compared between the two groups. Each bar indicates the mean \pm 2 SEM. $* P=0.009$ by Student's $t$ test.

parable periods relative to the onset of the disease; i.e., between 9 and $32 \mathrm{~d}$, mean $19.8 \mathrm{~d}$, in complication-positive patients, and between 9 and $33 \mathrm{~d}$, mean $18.1 \mathrm{~d}$, in complicationnegative patients.

Next, we performed Western blot analysis to determine whether the OD value obtained by ELISA actually reflected the binding of IgG to rYPM. When the paired sera obtained from the two patients were tested, the predominant binding of

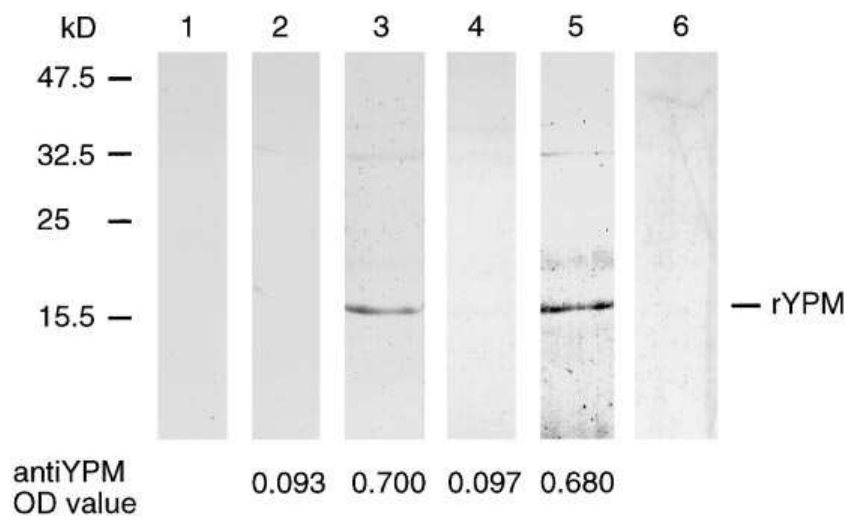

Figure 3. Western blot analysis of the two patients' sera. $1.0 \mu \mathrm{g}$ of rYPM (lanes 2-5), or rMBP as control (lanes 1 and 6 ), was electrophoresed and transferred to PVDF membrane. Sera obtained from patient 1 on day 6 (lanes 1 and 2) or day 21 (lane 3), and from the patient 2 on day 7 (lane 4 ) or day 16 (lanes 5 and 6 ) were diluted to 1:100 and applied to the membrane. Bound $\mathrm{IgG}$ was detected with peroxidase-conjugated $\mathrm{F}(\mathrm{ab})_{2}$ fraction of rabbit anti-human $\mathrm{IgG}$ and analyzed with an image analyzing system. Molecular weight markers are noted on the left and rYPM is indicated on the right. 


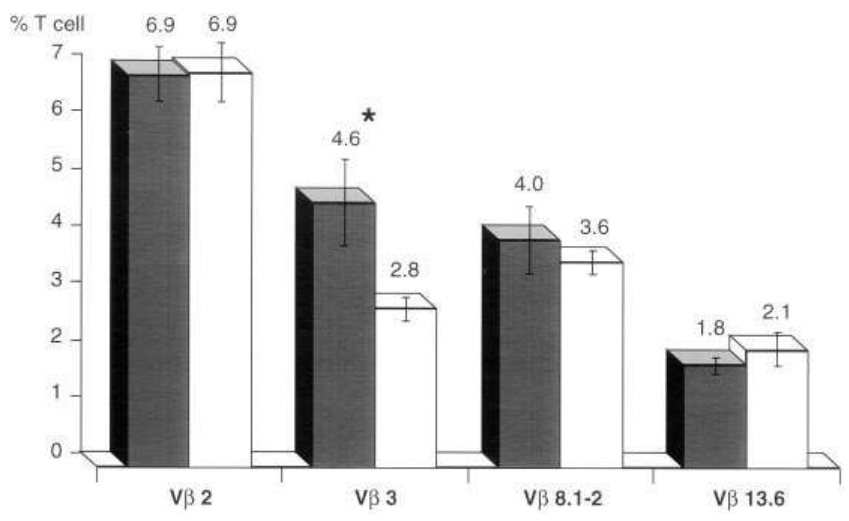

Figure 4. TCR V $\beta$ expression during acute $Y$. pseudotuberculosis infection. PBMC from the eight acute patients (filled columns) and 17 healthy children (open columns) were stimulated with anti-CD3 and IL-2 and analyzed for reactivity by immunofluorescence and flow cytometry using monoclonal anti-V $\beta$ antibodies. The percentages of $T$ cells bearing each $V \beta$ were calculated as described in Methods. Each bar indicates the mean \pm 2 SEM. $* P=0.004$ by Student's $t$ test.

IgG was seen against the $\sim 17.0-\mathrm{kD}$ protein that corresponds to rYPM in sera obtained on 16-21 d after the onset of illness (Fig. 3, lanes 3 and 5). The weak bands between 32.5 and 47.5 $\mathrm{kD}$ seen in Fig. 3, lanes 1-6 correspond to the proteins derived from host bacteria. The binding of IgG against the rMBP fusion protein simultaneously prepared with rYPM was not detected in the patients' sera (Fig. 3, lanes 1 and 6).

Expansion of $V \beta 3$ positive $T$ cells in PBMC from the acute phase patients. PBMC obtained from patients and healthy children were stimulated in culture with anti-CD3 antibody and IL-2. The T cell blasts were then analyzed for expression of $\mathrm{V} \beta 2,3,8.1 / 8.2$, and 13.6 by immunofluorescence and flow cytometry (Fig. 4). Significant increase of V $\beta 3$-bearing T cells was seen in the acute phase patients $(4.6 \pm 0.8$ vs. $2.8 \pm 0.2 \%$ [mean \pm SEM],$P=0.004)$. Other $\mathrm{V} \beta$ families examined showed little difference between the patients and controls. By using semiquantitative reverse transcription-PCR, we were

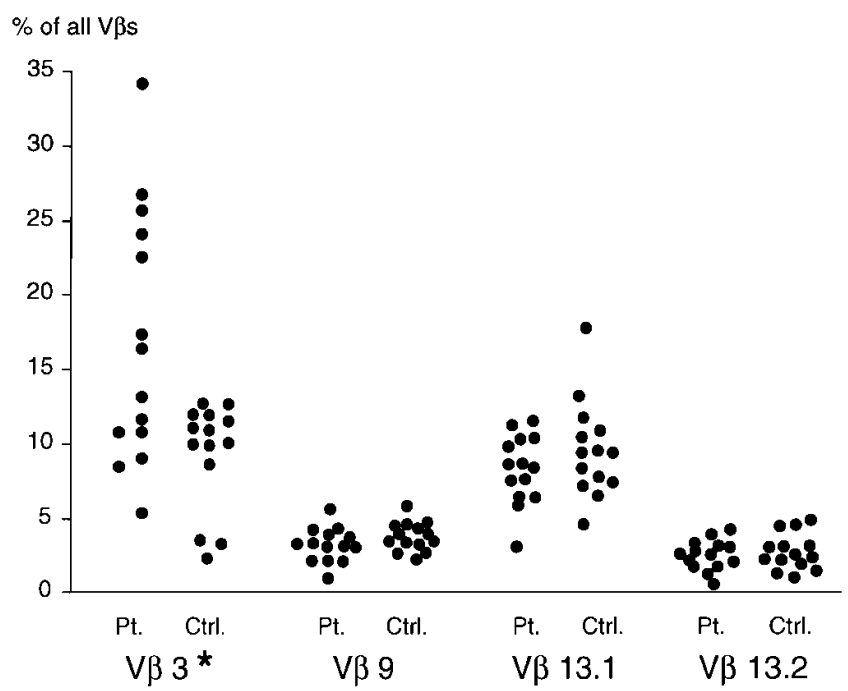

Figure 6. Individual data on the percentages of four YPM-responsive TCR V $\beta$ families in the same experiment as in Fig. 5. *In 7 out of 14 patients, the percentages of V $\beta 3$-positive $\mathrm{T}$ cells exceeded $2 \mathrm{SD}$ above the mean value obtained for healthy children.

able to confirm the immunofluorescence results. The summary of the PCR results was illustrated in Fig. 5. A marked increase in the percentages of $\mathrm{V} \beta 3 \mathrm{cDNA}$ was observed among the patients $(16.8 \pm 2.2$ vs. $9.8 \pm 1.1 \%, P=0.009)$. In 7 out of 14 patients, the percentages of V $\beta 3$-positive $\mathrm{T}$ cells exceeded $2 \mathrm{SD}$ above the mean value obtained for healthy children (Fig. 6). However, the percentages of V $\beta 9$-, 13.1-, and 13.2-bearing $\mathrm{T}$ cells were not increased in the patients, though these $\mathrm{T}$ cells were also stimulated and expanded by rYPM in the previous in vitro experiments $(11,20)$.

We next tried to determine whether the expansion of VB3bearing T cells was restricted to the acute phase of the illness. Paired samples from the acute and convalescence phase were available from seven patients, of whom three had elevated V $\beta 3$ during acute phase. These three patients had a significant

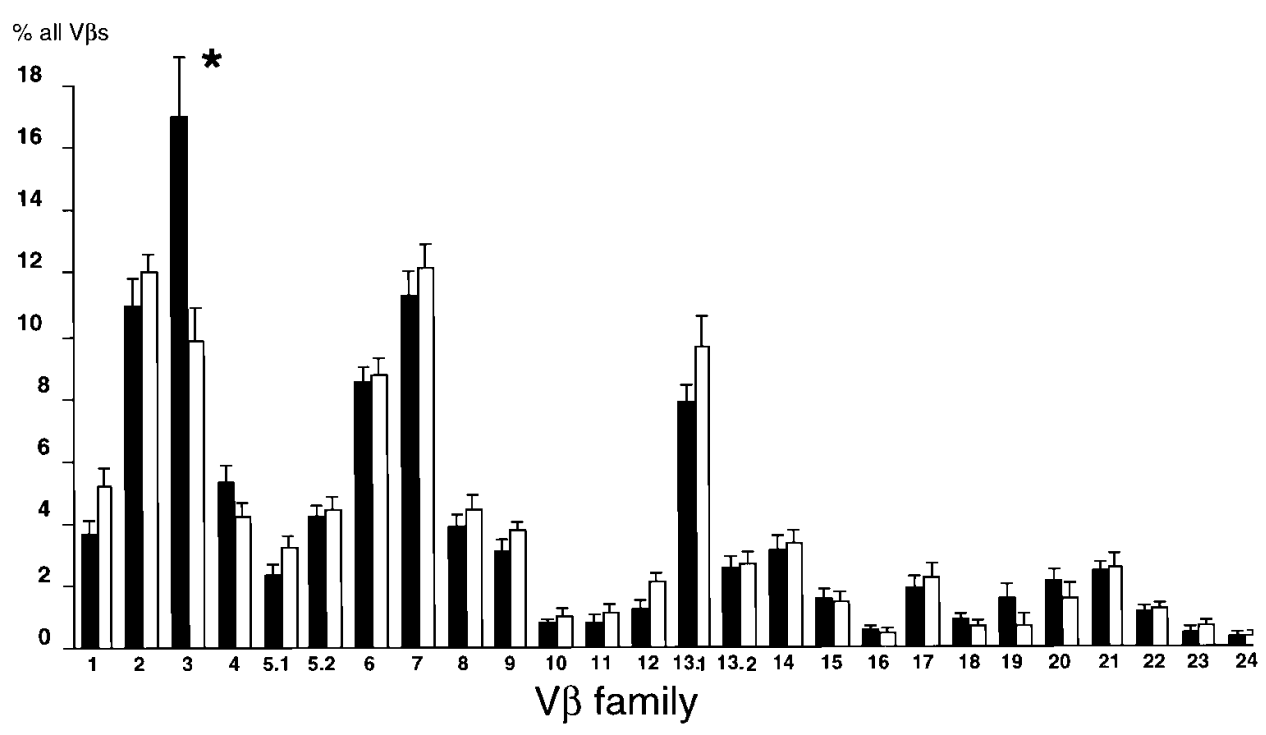

Figure 5. TCR V $\beta$ expression in T cells from 14 acute patients (filled bars) and 14 healthy children (open bars) analyzed by reverse transcription-PCR. Total RNA was extracted from the cultured PBMC as described in Methods before generation of first strand cDNA. Each reaction mixture contained specific oligonucleotide primers to expand the particular $\mathrm{V} \beta$ gene segment together with the $\mathrm{C} \alpha$ gene segment. Intensity of radioactivity of each band was quantitated with BAS2000 Bio Image Analyzer. The percentage of each $\mathrm{V} \beta$ among all $\mathrm{V} \beta$ families studied was calculated after normalization with the amount of coamplified $\mathrm{C} \alpha$ band. Each bar indicates the mean \pm 2 SEM. $* P=0.009$ by Student's $t$ test. 


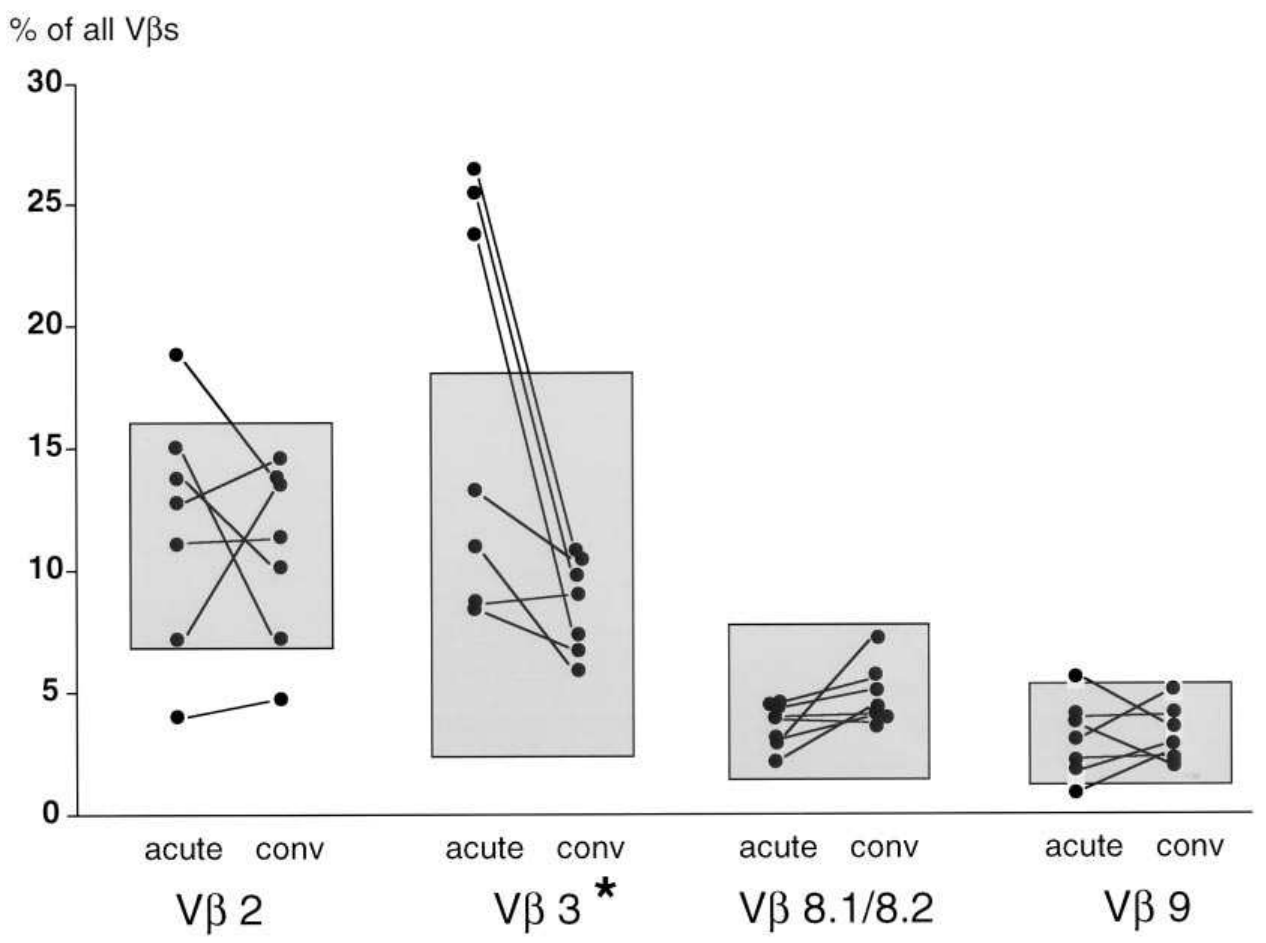

Figure 7. TCR V $\beta$ expression in $T$ cells from acute (within $20 \mathrm{~d}$ from the onset) and convalescent (later than $120 \mathrm{~d}$ ) patients analyzed by reverse transcription-PCR. Each line indicates the paired samples. The shaded areas represent the control mean \pm 2 SD for the percentages of each $\mathrm{V} \beta$-positive $\mathrm{T}$ cell determined for a group of healthy children. $* P=0.03$ by Student's paired $t$ test. decrease in the percentage of V $\beta 3$-bearing T cells between the acute and convalescence phase of their illness $(P=0.03$, Fig. 7).

Examination of V $\beta 3$-positive $T$ cells in the mesenteric lymph node. In most cases, $Y$. pseudotuberculosis enters the human body through the gastrointestinal tract and proliferates in Peyer's patches and mesenteric lymph nodes. In acute phase patients, the gastrointestinal symptoms are sometimes severe enough to mimic acute appendicitis. In a patient who underwent surgery because of severe abdominal pain, we were able to examine a V $\beta$ gene usage of mesenteric lymph node $\mathrm{T}$ cells by PCR (Table I). When a ratio of each $\mathrm{V} \beta$-expressing $\mathrm{T}$ cell in the mesenteric lymph node to PBMC was calculated, the increase was more than twofold in T cells bearing V 33 , 4, and 13.2 in a patient with yersiniosis, while only $\mathrm{T}$ cells bearing $\mathrm{V} \beta 4$ were elevated in a control patient with acute appendicitis by Klebsiella oxytoca.

In gut-associated lymphoid tissue, particularly in the intestinal intraepithelial lymphocytes, oligoclonal expansion of $\mathrm{T}$ cells that express distinct TCR V $\beta$ gene segments has been reported (30-32). Of these V $\beta$ families, V $\beta 2, \mathrm{~V} \beta 3$, and $\mathrm{V} \beta 6$ were frequently shared among intraepithelial lymphocytes from different individuals $(31,33)$. Therefore, in the next experiment, we analyzed the sequences of PCR-amplified TCR $\beta$ chain cDNA fragments that contain V $\mathrm{B} 3$ gene segments and junctional regions from mesenteric lymph node $\mathrm{T}$ cells of both yersiniosis and control patients (Table II). Among 20 clones examined, none of the V $\beta 3$ clones had the same junctional sequence, although the $\mathrm{J} \beta 2.7$ gene segment was preferentially used both in a yersiniosis patient $(40 \%)$ and a control $(45 \%)$. These data indicate that the elevated ratio of V $33 \mathrm{~T}$ cells in the mesenteric lymph node to the peripheral blood in a yersiniosis patient was not due to the clonotypic expansion usually seen in intraepithelial lymphocytes.

\section{Discussion}

The infection of $Y$. pseudotuberculosis is accompanied with multiple systemic symptoms as well as gastrointestinal tract symptoms. In our 33 patients, fever and polymorphous skin

Table I. TCR V 3 Expression in T Cells of Mesenteric Lymph Node (LN) and PBMC Analyzed by PCR*

\begin{tabular}{|c|c|c|c|c|c|c|c|c|c|c|c|c|c|c|c|c|c|c|c|c|c|c|c|c|c|c|c|}
\hline \multirow{2}{*}{$\begin{array}{l}\text { Source of } \\
\mathrm{T} \text { cells }\end{array}$} & & \multicolumn{26}{|c|}{ Vßs (\%) } \\
\hline & & 1 & 2 & 3 & 4 & 5.1 & 5.2 & 6 & 7 & 8 & 9 & 10 & 11 & 12 & 13.1 & 13.2 & 14 & 15 & 16 & 17 & 18 & 19 & 20 & 21 & 22 & 23 & 24 \\
\hline Patient ${ }^{\ddagger}$ & $\mathrm{LN}$ & 5 & 8 & $\underline{14}$ & $\underline{8}$ & 3 & 3 & 10 & 11 & 3 & 6 & 1 & $<1$ & 1 & 9 & $\underline{5}$ & 2 & 3 & $<1$ & 1 & 1 & $<1$ & 3 & 3 & $<1$ & $<1$ & $<1$ \\
\hline Patient & PBMC & 5 & 9 & 5 & 4 & 4 & 4 & 7 & 12 & 6 & 4 & 1 & 1 & 1 & 11 & 2 & 5 & 3 & 1 & 3 & 1 & $<1$ & 2 & 5 & 1 & $<1$ & $<1$ \\
\hline $\mathrm{Control}^{\S}$ & $\mathrm{LN}$ & 5 & 8 & 10 & $\underline{8}$ & 5 & 5 & 7 & 8 & 4 & 4 & 1 & 1 & 2 & 8 & 3 & 3 & 2 & 2 & 4 & 1 & 1 & 2 & 3 & 1 & $<1$ & $<1$ \\
\hline Control & PBMC & 6 & 7 & 12 & 4 & 4 & 4 & 6 & 12 & 5 & 3 & 1 & 1 & 2 & 12 & 2 & 4 & 1 & 1 & 3 & 1 & $<1$ & 1 & 3 & 2 & $<1$ & $<1$ \\
\hline
\end{tabular}

*PBMC and dissected mesenteric lymph node were frozen at $-80^{\circ} \mathrm{C}$ until extraction of RNA. PCR and data calculation were performed as described in Fig. 5 except that 24 cycles were used in PCR. ${ }^{*}$ The patient underwent surgery on day 6 of his illness. Y. pseudotuberculosis was isolated from his rectal swab and ascites. ${ }^{\S}$ The control patient was operated for appendicitis on day 3 of his illness. Klebsiella oxytoca was isolated from the removed tissue specimen. 
Table II. Sequence Analysis of Junctional Regions of TCR $\beta$ Chains Containing VB3 Element in T Cells of Mesenteric Lymph Node*

\begin{tabular}{|c|c|c|c|c|c|}
\hline \multicolumn{3}{|c|}{ Patient } & \multicolumn{3}{|c|}{ Control } \\
\hline $\mathrm{V} \beta$ & N-D $\beta-N$ & $\mathrm{~J} \beta$ & $\mathrm{V} \beta$ & $\mathrm{N}-\mathrm{D} \beta-\mathrm{N}$ & $\mathrm{J} \beta$ \\
\hline -LCASS & PLL & NTEAF-(1.1) & -LCAS & RTQ & TEAF-(1.1) \\
\hline -LCASS & SSTGL & TEAF-(1.1) & -LCASS & LFFLGH & YGYT-(1.2) \\
\hline —LCASS & ASGASP & $\mathrm{EAF}-(1.1)$ & -LCASS & LNRGILH & EKLF-(1.4) \\
\hline -LCASS & RSYRQGH & $\mathrm{AF}-(1.1)$ & -LCASS & LWFWDRGER & $\mathrm{NQPQH}-(1.5)$ \\
\hline -LCASS & FVVRSRD & GYT-(1.2) & -LCAS & RAPS & $\mathrm{NEQF}-(2.1)$ \\
\hline -LCASS & RAGTGFV & GYT-(1.2) & -LCASS & ALALY & $\mathrm{EQF}-(2.1)$ \\
\hline -LCASS & FFGTPW & YNEQF-(2.1) & -LCASS & LGGGGASW & $\mathrm{EQF}-(2.1)$ \\
\hline -LCAS & YDSYAGF & YNEQF-(2.1) & -LCASS & GQRE & $\mathrm{ELF}-(2.2)$ \\
\hline -LCASS & LGTGGF & $\mathrm{NEQF}-(2.1)$ & -LCASS & SAGTHVG & $\mathrm{LF}-(2.2)$ \\
\hline -LCAS & RSIRQV & $\mathrm{EQF}-(2.1)$ & -LCASS & SRPNLVTPRE & $\mathrm{QY}-(2.3)$ \\
\hline -LCASS & LSGGA & DTQY-(2.3) & -LCASS & LGDT & QETQY-(2.5) \\
\hline -LCAS & IGRH & SGANVLT-(2.6) & -LCASS & LRA & SYEQY-(2.7) \\
\hline -LCASS & LAV & SYEQY-(2.7) & -LCAS & PGGA & YEQY-(2.7) \\
\hline -LCASS & PLGGGH & YEQY-(2.7) & -LCASS & LPPRD & YEQY-(2.7) \\
\hline -LCAS & TGGE & YEQY-(2.7) & -LCASS & RND & YEQY-(2.7) \\
\hline -LCAS & YTGRTPY & YEQY-(2.7) & -LCASS & PGS & YEQY-(2.7) \\
\hline -LCASS & YPGHR & YEQY-(2.7) & -LCAS & RGQIL & YEQY-(2.7) \\
\hline -LCASS & LPIF & YEQY-(2.7) & -LCASS & SQLAGVV & YEQY-(2.7) \\
\hline -LCAS & KREPY & YEQY-(2.7) & -LCASS & LADLV & EQY-(2.7) \\
\hline -LCAS & ALAYKPT & $Q Y-(2.7)$ & -LCAS & RGQILY & EQY-(2.7) \\
\hline
\end{tabular}

*PCR-amplified TCR- $\beta$ chain cDNA fragments that contain V $\beta 3$ gene segments and junctional regions were ligated into plasmids and cloned. 20 clones were randomly selected and sequenced. Sequences are aligned as deduced amino acids (one letter code).

rash were observed in all patients and cervical lymphadenopathy and conjunctivitis were seen in 16 and 17 patients, respectively. Although many factors that confer virulence in this organism have been identified (34-36), most of them are involved in the organism's invasiveness and defense against the host's epithelial barrier and phagocytosis (37-40). Thus, it is conceivable that YPM, as a superantigen, might take part in the manifestation of systemic illnesses by activating a large proportion of $\mathrm{T}$ cells and inducing an excessive amount of inflammatory cytokines, as has been suggested in toxic shock syndrome (TSS) and streptococcal TSS (41-44). In this regard, we have first attempted to detect a footprint of YPM in patients with $Y$. pseudotuberculosis infection by measuring antibodies against YPM and by analyzing V $\beta$ expression of peripheral blood $\mathrm{T}$ cells.

By solid phase ELISA using rYPM, IgG anti-YPM antibodies were detected in $61 \%$ of acute phase patients with $Y$. pseudotuberculosis infection. In most cases, high titer was observed after the second week of the illness. In healthy control children and in IVGG preparations, we were unable to detect anti-YPM antibodies, although the presence of $\mathrm{IgG}$ antibodies to staphylococcal superantigens have been reported in IVGG preparations (45). The difference may be explained by a very low frequency of the Yersinia infection compared with the high distribution rate of $S$. aureus in Japan (46). More importantly, the patients with systemic symptoms such as transient renal failure, arthritis, lymphadenopathy, and coronary aneurysms had significantly higher titers of anti-YPM than the patients with gastrointestinal symptoms alone. Although the higher anti-YPM titer does not necessarily mean a higher production of YPM in the host, it implies, at least, that the host's immune system reacted to YPM more vigorously in the patients with systemic illnesses. Thus, it would be of interest to determine whether the presence of anti-YPM antibodies has a protective role against the initiation of the infection or the development of systemic illnesses and how long anti-YPM antibodies will remain in the patients after the first infection.

Superantigens have been implicated in the pathogenesis of staphylococcal TSS and streptococcal TSS (41-44). However, the $\mathrm{T}$ cells responses against superantigens are not uniform in these diseases. Selective expansion of T cells expressing V 32 has been reported in five of eight patients with TSS caused by TSST-1-producing S. aureus (47). On the other hand, selective depletion of V $\beta 1$-, 5.1-, and 12-bearing $\mathrm{T}$ cells was found in streptococcal TSS patients (48) and in mice injected with staphylococcal enterotoxin A (SEA) or B (SEB), deletion of V 33 or $\mathrm{V} \beta 8 \mathrm{~T}$ cells, respectively, were observed after an initial expansion of the same $\mathrm{V} \beta$-expressing $\mathrm{T}$ cells $(18,49,50)$. In our cases with $Y$. pseudotuberculosis infection, the percentage of V $\beta 3$-expressing $\mathrm{T}$ cells was elevated in the acute phase of the illness in 7 of 14 patients. In three patients examined serially, the elevated percentage of $\mathrm{V} \beta 3 \mathrm{~T}$ cells declined to the normal level after $120 \mathrm{~d}$ from the onset of the illness without evidence of clonal deletion. Currently, it is not known why the expansion of the particular $\mathrm{V} \beta$-expressing $\mathrm{T}$ cells is confined to $\mathrm{V} \beta 3$ and not to the other YPM-responsive V $\beta$ gene elements such as $\mathrm{V} \beta 9,13.1$, and 13.2. One possibility might be that the expansion of $\mathrm{V} \beta 3$-positive $\mathrm{T}$ cells is driven by an ordinary peptide 
antigen and not by a superantigen. This is unlikely for several reasons: first, the expansion of V $\beta 3$-bearing $T$ cells was seen as early as $6 \mathrm{~d}$ from the onset of the illness. Second, it is hardly expected that the MHC types of all the patients who had elevated V $33 \mathrm{~T}$ cells were identical. Third, we could not detect the same degree of expansion of the particular $V \alpha$-expressing $\mathrm{T}$ cells by PCR using 18 different $\mathrm{V} \alpha$-specific primers in a few patients with marked elevation of V $\beta 3$-positive $\mathrm{T}$ cells (data not shown). It would be more likely that the expansion of the particular $\mathrm{V} \beta$-expressing $\mathrm{T}$ cells is usually restricted to the local draining lymph nodes and, in the periphery, only an increase of a major subset, V $\beta 3$, might be detected with the prolonged exposure to YPM. The findings that the percentages of V $\beta 3$ - and V $\beta 13$.2-bearing $T$ cells were increased in the mesenteric lymph node compared with peripheral blood in a patient and that these V $\beta 3$ T cells exhibit a diversity in junctional sequences in TCR $\beta$ chain messages would support this hypothesis. However, because only a limited number of cases were analyzed, further studies regarding the TCR V $\beta$ gene usage in the gut-associated lymphoid tissue and in PBMC in yersiniosis patients are needed to confirm our hypothesis.

A variety of diseases have been reported as later sequelae of $Y$. pseudotuberculosis infection. These include reactive arthritis, Reiter's syndrome, ankylosing spondylitis, acute uveitis, chronic pancreatitis, Crohn's disease, acute renal failure due to acute interstitial nephritis, and Kawasaki syndrome (4-8, 23, 51-54). In these diseases, much attention has been paid to the function of the local inflammatory $T$ cells and antigen-presenting cells within the affected organ (55-59). It has been reported that there was marked predominance of Th1like (inflammatory) T cells compared with Th2-like (antigenproducing) $\mathrm{T}$ cells in Yersinia-induced reactive arthritis (59). It was also demonstrated that synovial fluid-derived CD8 T cells in such patients could mediate cytotoxicity on autologous EBtransformed B cells in the presence or absence of the bacteria (59). In the context of the pathogenesis of superantigens, it has been stressed that the activation of $T$ cells by superantigens favors the overproduction of proinflammatory cytokines such as TNF $\alpha$, TNF $\beta$, IL-1, IFN $\gamma$, and IL-6, which contribute to endothelial cell and organ damage $(43,44)$. In fact, serum IL-6 and $\mathrm{TNF} \alpha$ levels were also elevated in our acutely infected patients (data not shown). However, there have been reports that focused on the protective role of T cells in yersiniosis (60$63)$. These include the role of IFN $\gamma(61)$ and cytotoxic T cells against the Yop-derived peptide (63). Currently, it is not clear whether the superantigens work in concert with, or against these host's $\mathrm{T}$ cell-mediated protective immunity. In this regard, it would be of interest to study how and to what degree YPM influences the cytokine production pattern and cytotoxic activity of local resident $\mathrm{T}$ cells in these diseases.

In summary, our present data indicate that a superantigen, YPM, is actually produced by the organism in vivo and induces $\mathrm{IgG}$ response in patients with $Y$. pseudotuberculosis infection. In particular, the significantly higher antibody titer in patients with systemic symptoms and the expansion of the YPM-responsive V $\beta 3$-positive $\mathrm{T}$ cells in PBMC and in mesenteric lymph node suggest that this superantigen may have an important role during the disease process of $Y$. pseudotuberculosis infection. Future studies directed to the manner in which YPM is involved in these pathogenic immune cell responses will help to understand the possible autoimmune mechanism of the Yersinia-related diseases.

\section{Acknowledgments}

We thank Drs. K. Akagi, K. Yoshiya, K. Jo, and M. Sasaki for providing patients' samples, and Dr. D.Y.M. Leung for critical reading of the manuscript.

This work was supported in part by grants from the Ministry of Health and Welfare, the Japan Health Sciences Foundation, and the Japan Intractable Disease Research Foundation.

\section{References}

1. Knapp, W. 1958. Mesenteric adenitis due to Pasteurella pseudotuberculosis in young people. N. Engl. J. Med. 259:776-778.

2. Winblad, S., B. Nillehn, and N.H. Sternby. 1966. Yersinia enterocolitica (Pasteurella X) in human enteric infections. Br. Med. J. 2:1363-1366.

3. Krober, M.S., J.W. Bass, and P.J. Barcia. 1983. Scarlatiniform rash and pleural effusion in a patient with Yersinia pseudotuberculosis infection. J. Pediatr. 102:879-881.

4. Leino, R., A.L. Makela, A. Tiilikainen, and A. Toivanen. 1980. Yersinia arthritis in children. Scand. J. Rheumatol. 9:245-249.

5. Tertti, R., K. Granfors, O.P. Lehtonen, J. Mertsola, A.L. Makela, I. Valimaki, P. Hanninen, and A. Toivanen. 1984. An outbreak of Yersinia pseudotuberculosis infection. J. Infect. Dis. 149:245-250.

6. Saari, K.M., M. Maki, T. Paivonsalo, R. Leino, and A. Toivanen. 1986. Acute anterior uveitis and conjunctivitis following Yersinia infection in children. Int. Ophthalmol. 9:237-241.

7. Baba, K., N. Takeda, and M. Tanaka. 1991. Cases of Yersinia pseudotuberculosis infection having diagnostic criteria of Kawasaki disease. Contrib. Microbiol. Immunol. 12:292-296.

8. Davenport, A., B. O'Connor, and R. Finn. 1987. Acute renal failure following Yersinia pseudotuberculosis septicaemia. Postgrad. Med. J. 63:815-816.

9. Une, T. 1977. Studies on the pathogenicity of Yersinia enterocolitica. III Comparative studies between $Y$. enterocolitica and $Y$. pseudotuberculosis. Microbiol. Immunol. 21:505-516.

10. El-Maraghi, N.R.H., and N.S. Mair. 1979. The histopathology of enteric infection with Yersinia pseudotuberculosis. Am. J. Clin. Pathol. 71:631-639.

11. Abe, J., T. Takeda, Y. Watanabe, H. Nakao, N. Kobayashi, D.Y.M. Leung, and T. Kohsaka. 1993. Evidence for superantigen production by Yersinia pseudotuberculosis. J. Immunol. 151:4183-4188.

12. Uchiyama, T., A.T. Miyoshi, H. Kato, W. Fujimaki, K. Imanishi, and X.J. Yan. 1993. Superantigenic properties of a novel mitogenic substance produced by Yersinia pseudotuberculosis isolated from patients manifesting acute and systemic symptoms. J. Immunol. 151:4407-4413.

13. White, J., A. Herman, A.M. Pullen, R. Kubo, J.W. Kappler, and P. Marrack. 1989. The $\mathrm{V}$ beta-specific superantigen staphylococcal enterotoxin B: stimulation of mature $\mathrm{T}$ cells and clonal deletion in neonatal mice. Cell. 56:2735 .

14. Kappler, J., B. Kotzin, L. Herron, E.W. Gelfand, R.D. Bigler, A. Boylston, S. Carrel, D.N. Posnett, Y. Choi, and P. Marrack. 1989. V $\beta$-specific stimulation of human T cells by staphylococcal toxins. Science (Wash. DC). 244:811813 .

15. Fleischer, B. 1989. A conserved mechanism of T lymphocyte stimulation by microbial exotoxins. Microbiol. Pathol. 7:79-83.

16. Marrack, P., and J. Kappler. 1990. The staphylococcal enterotoxins and their relatives. Science (Wash. DC). 248:705-711.

17. Jardetzky, T.S., J.H. Brown, J.C. Gorga, L.J. Stern, R.G. Urban, Y. Chi, C. Stauffacher, J.L. Strominger, and D.C. Wiley. 1994. Three-dimensional structure of a human class II histocompatibility molecule complexed with superantigen. Nature (Lond.). 368:711-718.

18. Kawabe, Y., and A. Ochi. 1991. Programmed cell death and extrathymic reduction of ${\mathrm{V} B 8^{+}}^{+} \mathrm{CD}^{+} \mathrm{T}$ cells in mice tolerant to Staphylococcus aureus enterotoxin B. Nature (Lond.). 349:245-248.

19. O'Hehir, R.E., and J.R. Lamb. 1990. Induction of specific clonal anergy in human T lymphocytes by Staphylococcus aureus enterotoxins. Proc. Natl. Acad. Sci. USA. 87:8884-8888.

20. Ito, Y., J. Abe, K. Yoshino, T. Takeda, and T. Kohsaka. 1995. Sequence analysis of the gene for a novel superantigen produced by Yersinia pseudotuberculosis and expression of the recombinant protein. J. Immunol. 154:5896-5906.

21. Yoshino, K., T. Ramamurthy, G.B. Nair, H. Fukushima, Y. Ohtomo, N. Takeda, S. Kaneko, and T. Takeda. 1995. Geographical heterogeneity between Far East and Europe in prevalence of ypm gene encoding the novel superantigen among Yersinia pseudotuberculosis strains. J. Clin. Microbiol. 33:33563358 .

22. Carniel, E., and H.H. Mollarat. 1990. Yersiniosis. Comp. Immun. Microbiol. Infect. Dis. 13:51-58.

23. Sato, K., K. Ouchi, and M. Taki. 1983. Yersinia pseudotuberculosis infection in children, resembling Izumi fever and Kawasaki syndrome. Pediatr. Infect. Dis. 2:123-126.

24. Inoue, M., H. Nakashima, O. Ueba, T. Ishiba, H. Date, S. Kobashi, K. 
Takagi, T. Nishu, and M. Tsubokura. 1984. Community outbreak of Yersinia pseudotuberculosis. Contrib. Microbiol. Immunol. 28:883-891.

25. Somov, G.P., and I.L. Martinevsky. 1973. New facts about pseudotuberculosis in the USSR. Contrib. Microbiol. Immunol. 2:214-216.

26. Maina, C.V., P.D. Riggs, A.G. Grandea III, B.E. Slatko, L.S. Moran, J.A. Tagliamonte, L.A. McReynolds, and C. Guan. 1988. A vector to express and purify foreign proteins in Escherichia coli by fusion to, and separation from, maltose binding protein. Gene. 74:365-373.

27. Leung, D.Y.M., R. Harbeck, P. Bina, R.F. Reiser, E. Yang, D.A. Norris, J.M. Hanifin, and H.A. Sampson. 1993. Presence of IgE antibodies to staphylococcal exotoxins on the skin of patients with atopic dermatitis. J. Clin. Invest. 92:1374-1380.

28. Choi, Y., B. Kotzin, L. Herron, J. Callahan, P. Marrack, and J. Kappler. 1989. Interaction of Staphylococcus aureus toxin "superantigens" with human T cells. Proc. Natl. Acad. Sci. USA. 86:8941-8945.

29. Robinson, M.A. 1991. The human T cells receptor $\beta$-chain gene complex contains at least 57 variable gene segments. Identification of six $\mathrm{V} \beta$ genes in four new gene families. J. Immunol. 146:4392-4397.

30. Balk, S.P., E.C. Ebert, R.L. Blumenthal, F.V. McDermott, K.W. Wucherpfennig, S.B. Landau, and R.S. Blumberg. 1991. Oligoclonal expansion and CD1 recognition by human intestinal intraepithelial lymphocytes. Science (Wash. DC). 253:1411-1415.

31. Kerckhove, C.V., G.J. Russell, K. Deusch, K. Reich, A.K. Bhan, H. DerSimonian, and M.B. Brenner. 1992. Oligoclonality of human intestinal intraepithelial T cells. J. Exp. Med. 175:57-63.

32. Blumberg, R.S., C.E. Yockey, G.G. Gross, E.C. Ebert, and S.P. Balk. 1993. Human intestinal intraepithelial lymphocytes are derived from a limited number of $\mathrm{T}$ cell clones that utilize multiple $\mathrm{V} \beta \mathrm{T}$ cell receptor genes. J. Immunol. 150:5144-5153.

33. Gross, G.G., V.L. Schwartz, C. Stevens, E.C. Ebert, R.S. Blumberg, and S.P. Balk. 1994. Distribution of dominant T cell receptor $\beta$ chains in human intestinal mucosa. J. Exp. Med. 180:1337-1344.

34. Cornelis, G., Y. Laroche, G. Balligand, M.P. Sory, and G. Wauters. 1987. Yersinia enterocolitica, a primary model for bacterial invasiveness. Rev. Infec. Dis. 9:64-87.

35. Brubaker, R.R. 1991. Factors promoting acute and chronic diseases caused by Yersiniae. Clin. Microbiol. Rev, 4:309-324.

36. Isberg, R.R., and S. Falkow. 1985. A single genetic locus encoded by Yersinia pseudotuberculosis permits invasion of cultured animal cells by Escherichia coli K-12. Nature (Lond.). 317:262-264.

37. Bolin, I., and W.H. Wolf. 1988. The plasmid-encoded Yop2b protein of Yersinia pseudotuberculosis is a virulence determinant regulated by calcium and temperature at the level of transcription. Mol. Microbiol. 22:237-245.

38. Rosqvist, R., A. Forsberg, M. Rimpilainen, T. Bergman, and H. WolfWatz. 1990. The cytotoxic protein YopE of Yersinia obstructs the primary host defense. Mol. Microbiol. 4:657-667.

39. Bliska, J.B., K. Guan, J.E. Dixon, and S. Falkow. 1991. Tyrosine phosphate hydrolysis of host proteins by an essential Yersinia virulence determinant. Proc. Natl. Acad. Sci. USA. 88:1187-1191.

40. Rosqvist, R., K.E. Magnusson, and W.H. Wolf. 1994. Target cell contact triggers expression and polarized transfer of Yersinia YopE cytotoxin into mammalian cells. EMBO (Eur. Mol. Biol. Organ.) J. 13:964-972.

41. Bohach, G.A., D.J. Fast, R.D. Nelson, and P.M. Schlievert. 1990. Staphylococcal and streptococcal pyrogenic toxins involved in toxic shock syndrome and related illnesses. Crit. Rev. Microbiol. 17:251-272.

42. Kotzin, B.L., D.Y.M. Leung, J. Kappler, and P. Marrack. 1993. Superantigen and their potential role in human disease. Adv. Immunol. 54:99-166.

43. Miethke, T., C. Wahl, D. Regele, H. Gaus, K. Heeg, and H. Wagner. 1993. Superantigen mediated shock: a cytokine release syndrome. Immunobiol. 189:270-284.

44. Kotb, M. 1995. Bacterial pyrogenic exotoxins as superantigens. Clin. Microbiol. Rev. 8:411-426.
45. Takei, S., Y.K. Arora, and S.M. Walker. 1993. Intravenous immunoglobulin contains specific antibodies inhibitory to activation of T cells by staphylococcal toxin superantigens. J. Clin. Invest. 91:602-607.

46. Fukami, T. 1986. Frequency of Yersinia species isolated from sporadic patients with diarrhea (in Japanese). Media Circle. 31:314-318.

47. Choi, Y., J.A. Lafferty, J.R. Clements, J.K. Todd, E.W. Gelfand, J. Kappler, P. Marrack, and B.L. Kotzin. 1990. Selective expansion of T cells expressing V 32 in toxic shock syndrome. J. Exp. Med. 172:981-984.

48. Watanabe-Ohnishi, R., D.E. Low, A. McGeer, D.L. Steevens, P.M Schlievert, D. Newton, B. Schwarz, B. Kreiswirth, and M. Kotb. 1995. Selective depletion of $\mathrm{Vb}$-bearing $\mathrm{T}$ cells in patients with severe invasive group A streptococcal infections and streptococcal toxic shock syndrome. J. Infect. Dis. 171: $74-84$.

49. Wahl, C., T. Miethke, K. Heeg, and H. Wagner. 1993. Clonal deletion as direct consequence of an in vivo T cell response to bacterial superantigen. Eur. J. Immunol. 23:1197-1200.

50. McCormack, J.E., J.E. Callahan, J. Kappler, and P.C. Marrack. 1993 Profound deletion of mature $\mathrm{T}$ cells in vivo by chronic exposure to exogenous superantigen. J. Immunol. 150:3785-3792.

51. Blaser, M.J., R.A. Miller, J. Lacher, and J.W. Singleton. 1984. Patients with active Crohn's disease have elevated serum antibodies to antigens of seven enteric bacterial pathogens. Gastroenterology. 87:888-894.

52. Treacher, D.F., and D.P. Jewell. 1985. Yersinia colitis associated with Crohn's disease. Postgrad. Med. J. 61:173-174.

53. Granfors, K., S. Jalkanen, R. Von Essen, R.R. Lahesmaa, O. Isomaki, H.K. Pekkola, P.R. Merilahti, R. Saario, H. Isomaki, and A. Toivanen. 1989. Yersinia antigens in synovial fluid cells from patients with reactive arthritis. $N$. Engl. J. Med. 320:216-221.

54. Hammer, M., H. Zeidler, S. Klimsa, and J. Heesemann. 1990. Yersinia enterocolitica in the synovial membrane of patients with Yersinia-induced arthritis. Arthritis Rheum. 33:1795-1801.

55. Life, P.F., N.J. Viner, P.A. Bacon, and J.S. Gaston. 1990. Synovial fluid antigen-presenting cells unmask peripheral blood $\mathrm{T}$ cell responses to bacterial antigens in inflammatory arthritis. Clin. Exp. Immunol. 79:189-194.

56. Hermann, E., A.W. Lohse, d.Z.R. Van, E.W. Van, W.J. Mayet, P. Probst, T. Poralla, z.B.K. Meyer, and B. Fleischer. 1991. Synovial fluid-derived Yersinia-reactive $\mathrm{T}$ cells responding to human $65-\mathrm{kDa}$ heat-shock protein and heat-stressed antigen-presenting cells. Eur. J. Immunol. 21:2139-2143.

57. Probst, P., E. Hermann, z.K.B. Meyer, and B. Fleischer. 1993. Multiclonal synovial $\mathrm{T}$ cell response to Yersinia enterocolitica in reactive arthritis: the Yersinia $61-\mathrm{kDa}$ heat-shock protein is not the major target antigen. J. Infect. Dis. 167:385-391.

58. Lahesmaa, R., H. Yssel, S. Batsford, R. Luukkainen, T. Mottonen, L. Steinman, and G. Peltz. 1992. Yersinia enterocolitica activates a T helper type 1-like T cell subset in reactive arthritis. J. Immunol. 148:3079-3085.

59. Hermann, E., D.T. Yu, z.K.B. Meyer, and B. Fleischer. 1993. HLA B27-restricted CD8 T cells derived from synovial fluids of patients with reactive arthritis and ankylosing spondylitis. Lancet (N. Am. Ed.). 342:646-650.

60. Autenrieth, I.B., U. Vogel, S. Preger, B. Heymer, and J. Heesemann. 1993. Experimental Yersinia enterocolitica infection in euthymic and T-celldeficient athymic nude C57BL/6 mice: comparison of time course, histomorphology, and immune response. Infect. Immun. 61:2585-2595.

61. Autenrieth, I.B., M. Beer, E. Bohn, S.H. Kaufmann, and J. Heesemann. 1994. Immune responses to Yersinia enterocolitica in susceptible BALB/c and resistant C57BL/6 mice: an essential role for gamma interferon. Infect. Immun. 62:2590-2599.

62. Noll, A., A. Roggenkamp, J. Heesemann, and I.B. Autenrieth. 1994. Protective role for heat shock protein-reactive $\alpha \beta$ T cells in murine yersiniosis. Infect. Immun. 62:2784-2791.

63. Starnbach, M.N., and M.J. Bevan. 1994. Cells infected with Yersinia present an epitope to class I MHC-restricted CTL. J. Immunol. 153:1603-1612. 